\title{
The problem of social trust in the context of system methodology
}

\author{
Zoya Dmitrievna Denikina ${ }^{{ }^{*}}$, Pirmagomed Shikhmagomedovich Shikhgafizov ${ }^{2}$, Aleksandr \\ Valentinovich Sablukov ${ }^{3}$, Vyacheslav Leonidovich Primakov ${ }^{3}$, and Valery Aleksandrovich \\ Lapshov $^{3}$
}

\footnotetext{
${ }^{1}$ Financial University under the Government of the Russian Federation, Department of Humanities, Moscow, Russia.

${ }^{2}$ Financial University under the Government of the Russian Federation, Department of Sociology, Moscow, Russia

${ }^{3}$ Moscow State Linguistic University, The Department of Social Sciences at the Institute of International Relations and Social and Political Sciences, Moscow, Russia
}

\begin{abstract}
The article examines the epistemological status of the phenomenon of social trust. The research purpose is to explicate the concept of trust in connection with the fundamental transformation of socio-historical practice and social knowledge. The priority methodological task is to study the problem within the framework of the system methodology evolution and consider the parameters of trust in the intervals of non-classical and post-non-classical systems analysis. The study is based on a philosophical-scientific paradigm approach. Epistemological situations of autonomous and conventional application of different paradigms are modeled in the study of the phenomenon of social trust. In non-classical systems analysis, social trust is an internal characteristic of a society-system in the mode of its correct functioning. Social trust is one of the social order mechanisms. Social trust is also associated with subjective trust, ordering the interaction of subjects. Intersubjective interactions entail the legitimation of the social order. The transformation of social trust in the modern world is associated with trends in the reduction of the role of normativity, the fragmentation of socio-historical existence. There appears augmented reality, which contains to a certain extent the elements of pseudo-being. Subjective social trust can no longer support holistic meanings. In a situation of change in epistemological attitudes to determine the specifics of social trust, a systems analysis of weakly and highly non-equilibrium states of the intersystem environment is promising. Social order formulas are still inadequate for modeling intersystem environmental states (relations between states, blocs, unions, etc.). Within the framework of the post-non-classical systemic methodology, social trust refers to the signs of social holism. Social trust contributes to the emergence of stable intersystem conditions, the formation of a regulatory environment, which becomes an acting unit. Social trust in all philosophical-scientific paradigms is indicative of the rationality of social-historical existence.
\end{abstract}

\footnotetext{
* Corresponding author: zooden@mail.ru
} 
Keywords: social trust, intersystem conditions, system environment, ontological trust, epistemological trust, value-based trust

\section{Introduction}

The problem of trust turns out to be a subject and methodological area where the interests of social philosophy, theoretical sociology, philosophy of history and philosophy of politics coincide thematically [1-3]. This general subject area can be designated as the systemic nature of the socio-political order. The initial hypothesis is that in post-non-classical social science, a systems analysis of any social phenomenon, including trust, is an alternative to postmodern thinking.

The systemic approach to social processes was developed by T. Parsons in the 1960s 1970s [4]. His conceptual conclusions are still relevant today, but the proposed social landscape is not modeled within the framework of a super-complex, highly non-equilibrium, non-linear, baseless ontology. According to Parsons, intrasystem processes are effectively comprehended, and the interaction of the system with the external environment, the equilibrium environment is represented by the adaptation mechanism. As defined by Parsons, a social system is that constituted by states and processes of social interaction between acting units [5]. Accordingly, the key role is assigned to the interaction of individuals, their subjective ideas. In non-classical sociology, the phenomenon of trust is studied in the socio-psychological terms, as subjective meanings of actions. It is assumed that the systemic effect of trust arises at the moment of intersubjective meanings [6] common to interacting subjects (according to A. Schutz's phenomenological social theory [7], meanings are constituted in the stream of life experience) [8]. A subjective component of the phenomenon of trust is so great that it is impossible to secure public order without it.

The process of legitimizing social reality is another side of social trust. Legitimation [9] defines social reality as an objective reality [10]. According to M. Weber [11], a social subject gives reality the status of significance and universality. In any case, the social order, which includes subjective trust, is an intrinsic characteristic of society. It is necessary to highlight a non-classical idea that a social system functions correctly when there are social interactions based on comprehending the meaning of the actions of another individual. The system functions irrationally if social interactions are not mediated by trusting attitudes, conviction in appropriate response actions.

According to Parsons, the basic principle of the system is a long-term order. Any functional tasks within the system work for its integrity. In this case, the function determines "some necessary conditions for the preservation of independent existence of the system within some environment" [5]. An unpredictable change in the priorities of significance is dangerous for the system. Defending the system from a plurality of normative aspirations of subjects, Parsons uses the concept of "functional imperatives" "universally shared rules". These rules are mainly drawn from practical (exemplary) administration tasks, and ensuring credibility of these rules depends on the ability of the system to socialize these rules. During the socialization, people receive a set of targeted landmarks that motivate the acceptance of the system policy [5]. Thus, a systems analysis of the phenomenon of social trust in the "pre-postmodern" period indicates the internal functional features of the system, its normativity. According to Parsons' system theory, the normativity of the system is determined by the ability to solve general problems of 
adaptation, integration, goal achievement and sampling [5]. Highlighting the simplest relationships in the system (belief, purpose, norm and value), Parsons points to the systemic ordering of the interaction of subjects, their trusting relationships.

\section{$2 \quad$ Materials and methods}

The methodological basis of the study consists of scientific works that reveal the problem of social trust in the $20^{\text {th }}-21^{\text {st }}$ centuries $[7,8,10,12-19]$. The further epistemological history of the phenomenon of social trust is associated with two factors: the fundamental transformation of socio-historical knowledge and the evolution of systems analysis. The state of socio-historical existence can be expressed in a concentrated way in the word "loss". There is a loss of integrity and a threat of loss of economic, political sovereignty of national-cultural identity. There is a loss of systematicity, aggressive block thinking, getting out of contractual relations becomes the norm [20]. There is a loss of normativity, the prestige of international organizations and the role of international institutions decrease. There is a loss of responsibility as the reverse side of trust. Not only regularities, but even stable tendencies are not traced in the fragmented socio-historical existence. Communications between the subjects of local existence are phased out, the common ontological space is narrowed. In social knowledge, procedural practices are leveled: military expertise, environmental expertise, etc. Due to the impossibility of determining the degree of penetration of reality and pseudo-reality, subjective assessments lose their holistic meaning and are no longer a type of reflection [21]. Not only reasons, but even the conditions of existence are not collectively comprehended. The social contract within individual states and the outward-directed discourse are destroyed. "Structural and functional models, a systemic idea of sociocultural life were replaced by pluralism of the initial principles of organizing experience, the lack of a universal system of correlating the truth or falsity of statements... The postmodern worldview opposes the "dictatorship of the common"..." [22].

In the context of globalization, epistemological attitudes are undergoing significant changes. Currently, synergetics and the theory of autopoiesis are looking for sources and arguments for their conceptual models in a highly complex socio-historical world. In the authors' opinion, a systems analysis of weakly and highly non-equilibrium states of the intersystem environment is promising for determining the specifics of social trust.

\section{$3 \quad$ Results}

In modern systems analysis, it is necessary to take the next step "to admit that the environment for any system is also a higher-order system and not just a field of chaosogenic impacts... In organic integrity, any element is a bearer of qualities of the whole, only in a reduced potential state" [14].

One could hardly disagree with U. Beck's idea of the need to abandon "methodological nationalism", which considers the state in national isolation, and the transition to "methodological cosmopolitanism", which makes it possible to talk about human society as a whole, about the connection of local society with all humanity. In his interdisciplinary analysis, U. Beck comes to the conclusion that "within the national-state modernity it was assumed that in the world of national players there are only two paths to stability: equilibrium (balance of intimidation) or hegemony. On the contrary, in the age of 
globalization the following alternative is fair: the loss of national sovereignty or transnational cooperation" [12].

\section{Discussion}

In the authors' opinion, it is methodologically productive to analyze modern socio-historical ontology as the interaction of the system and the environment. The specificity of this process lies in the fact that the mode of a highly non-equilibrium state is inherent only in some national-state formations (systems), while the external environment with intersystem interactions does not comply with an equilibrium ontological description. Even synergetic scenarios are not correlated with this existence of the intersystem environment, the conceptual formula "order-chaos-order" is not yet adequate for modeling intersystem environmental states, in which bifurcation diversity is not observed and stable attractors do not appear.

The ontology of a stable world cannot be unipolar: on the one hand, equilibrium crisis-free autonomy of the state (system) and, on the other hand, a fragmented highly non-equilibrium external environment with a minimum of common intersystem interactions. If the state wants to remain a legal actor, a subject of political-economic decision-making, it is involved in the mechanism for creating intersystem interaction and maintaining trust.

Trust is related to the category of ontological signs of the common, which is manifested in the single. If a group of states recognizes international law, applies the recommendations of international organizations, it has a similar reflection on historical and current events and there appears the effect of socio-historical trust. The emergence of conditions favorable for interstate relations serves as an indicator of the resumption of linear functional and causal determination. This means that in the intersystem environment, one can trace stable trends that the goals lead to predictable results, while the identified reasons entail unambiguous consequences. Thus, according to F. Fukuyama [13], a similar perception of values leads to predictability.

The conditions make the environment normative and value-significant for national states (systems-subjects). To a large extent, intersystem conditions are "man-made", they are formed through special efforts of the subjects of international communication. In this sense, trust is an attributive characteristic of intersystem conditions. Trust as a parameter of intersystem conditions also contributes to the dynamics of intrasystem interactions, the emergence of new functions, the renewal of structures, and the desired choice is made in intersystem interactions. Conditions are the environment for cause-and-effect relationships. The presence of an element of trust in them removes the uncertainty in cause-and-effect relationships. It becomes possible to predict a range of consequences, and the conditionality of political-economic events becomes linear.

Stable conditions lead to ontological equality and balance, prolongation of agreements without absolutizing the current tasks. Cause-and-effect relationships are constantly transforming, and intersystem conditions set the long-term background of these changes. It appears that the conditions are always essentially determined, but their existence is discontinuous: they may or may not be, the environment always exists, and it can be weakly or highly non-equilibrium.

In contrast to the conditions, the intersystem environment has the following ontological meaning. It can be an actor, and its ontological carriers are social groups, parties, elites, states, economic and political unions, etc. According to N. Luhmann, a system always delimits itself from the environment, preserving its essential values [23-25]. 


\section{Conclusion}

It can be suggested that in the systemic autopoiesis the environment is also essentially defined and ontologically not aggressive and, in this case, intrasystem decisions "heal" the systemic states.

Weakly non-equilibrium geopolitical processes are favorable for intersystem and intrasystem communications. Trust between the system and the environment is transformed into a self-organization mechanism. Trust as a parameter of the intersystem environment contributes to the preservation of the identity of each system, in political terminology national security $[26,27]$. That is why the role of international law and the normative intersystem environment is great. Trust is a sign of the rationality of social-historical existence, trust helps to restore essentialism, logic and holistic values [28]. Ontological trust is expressed in relation to the past (historical reality); in relation to the present (socio-political and economic reality); in relation to the future (global virtual reality). Epistemological trust abandons simulacra, returns to expert knowledge, to the recognition of coherent and relative truth. Axiological trust appeals to the norm, to the recognition of atomistic values (the role of an individual and the sovereignty of the state) and holistic values within the framework of universal human ideas and supranational values [29].

Thus, social trust as a scientific category is actively included in the process of complex socio-philosophical comprehension. The problem of trust is one of the most demanded topics of interdisciplinary knowledge [30]. The study of trust in the perspective of modern systems analysis provides an idea that there is a fundamental determinism behind the fundamental indeterminism of social interactions [31, 32], the existence of a system in an irrational environment threatens its identification and limits the ways of reproduction and self-regulation.

\section{References}

1. P. Sztompka, Socjologia. Analiza społeczeństwa [Sociology. Analysis of society] (Wydawnictwo Znak, Kraków, 2002)

2. P. Sztompka, Trust: A Sociological Theory (Cambridge University Press, Cambridge, 1999)

3. P. Sztompka, Zaufanie fundament społ eczeństwa [Trust the foundation of fellowship] (Wydawnictwo Znak, Krakow, 2007)

4. T. Parsons, The Concept of Society: The Components and Their Interrrelations, in T. Parsons (ed), Societies: Evolutionary and Comparative. Perspectives (Prentice-Hall, Englewood Cliffs, 1966)

5. T. Parsons, The system of modern societies (Prentice-Hall, Inc., Englewood Cliffs, 1971)

6. A. Schütz, G. Walsh, F. Lehnert, The Phenomenology of the Social World (Northwestern University Press, 1967)

7. A. Schütz, The Structures of the Life-World (Northwestern University Press, Evanston, 1973)

8. A. Schütz, On Phenomenology and Social Relations: Selected Writings, in H. Wagner (ed) (University of Chicago Press, Chicago, 1970) 
9. M. Weber, Gesammelte Aufsätze zur Religionssoziologie [Collected essays on the sociology of religion] (Mohr Siebeck GmbH \& Co, Tubingen, 1920)

10. P. Berger, L.T. Luckmann, The Social Construction of Reality. A Treatise on sociology of Knowledge (Penguin Press, 1966)

11. M. Weber, Wirtschaft und Gesellschaft [Economy and Society] (Tübingen, 1972)

12. U. Beck, Chto takoe globalizatsiya? [What is globalization?] (Moscow, 2001)

13. F. Fukuyama, Konets istorii i Poslednii chelovek [The End of History and the Last Man] (Free Press, 1992)

14. S.V. Shachin, Zakony dialektiki i printsipy posledovatelnosti: opyt novogo obosnovaniya [The laws of dialectics and the principles of consistency: The experience of a new justification] (LENAND, Moscow, 2014)

15. M. Woolcock, Theory Soc, 27, 151-208 (1998)

16. P.C. Bauer, Socius: Soc Res Dynam World, 4, 1-14 (2018)

17. M.J. Brandt, G. Wetherell, P.J. Henry, Polit Psychol, 36, 761-768 (2015)

18. A.K. Clark, M.A. Eisenstein, Soc Sci Res, 42, 361-375 (2013)

19. C. Dawson, Sociology, 53, 590-599 (2019)

20. R. Inglehart, The Silent Revolution in Europe: Changing Values and Political Styles among Western Publics (Princeton, New York, 1977)

21. J. Alexander, Europ J Soc Theory, 5(1), 5-85 (2002). https://doi.org/10.1177/1368431002005001001

22. M.V. Bakhtin, Epistemologiya sotsialno-istoricheskogo znaniya (modeli istorii i filosofsko-antropologicheskie predstavleniya) [Epistemology of socio-historical knowledge (models of history and philosophical and anthropological representations)] (VNIIgeosystem, Moscow, 2013)

23. N. Luhman, Okologische Kommunikation: kann die moderne Gesell-schaft sich auf okologische Gefahrdungen einstellen? [Ecological communication: can modern society adapt to ecological hazards?] (Opladen, 1986)

24. N. Luhmann, Soziologische Aufklärung 6: Die Soziologie und der Mensch, 113-124 (1995)

25. N. Luhmann, Die Gesellschaft der Gesellschaft [The Society of society], in Gesellschaft als soziales, v.1 System, 11-189 (Suhrkamp Verlag, Frankfurt am Main, 1997)

26. J. Delhey, K. Newton, Eur Soc, 5, 93-137 (2003)

27. P.T. Dinesen, R. Bekkers, The foundations of individuals generalized social trust: a review, in P.A.M. Van Lange, B. Rockenbach, T. Yamagishi (eds), Trust in Social Dilemmas, 77-99 (Oxford University Press, 2017). https://doi.org/10.1093/oso/9780190630782.003.0005

28. V. Ilyina, SHS Web Conf, 88, 01007 (2020). https://doi.org/10.1051/shsconf/20208801007

29. P.T. Dinesen, K.M. Sønderskov, Am Socio Rev, 80, 550-573 (2015)

30. F. Fukuyama, Doverie. Sotsialnye dobrodeteli i put k protsvetaniyu [Trust. Social virtues and the path to prosperity] (LLC "Publishing House AST", Moscow, 2004)

31. A. Giddens, Consequences of Modernity (Stanford, 1990) 
32. R. Sztompka, Trust: A Soziological Theory (CUP, Cambridge, 1999) 